\title{
Kidney Cancer pT3 TNM Finding v6
}

National Cancer Institute

\section{Source}

National Cancer Institute. Kidney Cancer pT3 TNM Finding v6. NCI Thesaurus. Code C63566.

Kidney cancer with tumor extending into major veins or invading the adrenal gland or perinephric tissues, but not extending beyond Gerota's fascia. (from AJCC 6th Ed.) 